\author{
Prof. dr. sc. Petar Bačić \\ Pravni fakultet Sveučilišta u Splitu
}

\title{
NAJAVA MODERNIH GARANCIJA PRAVA U KORČULANSKOM STATUTU
}

\author{
UDK: 34 : 352 (497.5 Korčula) (094.7) \\ DOI:10.31141/zrpfs.2021.58.141.729 \\ Izvorni znanstveni rad \\ Primljeno: 10. prosinca 2020.
}

U radu autor ukazuje na relevantne odredbe i značaj Magne Carte kao preteče modernih deklaracija o pravima, te se kratko osvrće na suvremena shvaćanja i uvriježene klasifikacije ljudskih prava, sustave njihove zaštite, a detaljnije na usporedive odredbe Korčulanskog statuta koje, prema njegovom mišljenju, nesumnjivo predstavljaju nagovještaj modernih garancija prava i sloboda. Pritom u Korčulanskom statutu pronalazi i neke odredbe, poput, primjerice, ograničavanja trgovanja robljem, koje Magna Carta ne poznaje. Autor polazi od toga da pri povlačenju paralela između srednjovjekovnih i modernih dokumenata i procjeni značenja pojedinih odredaba i instituta nužno treba biti oprezan, a pitanje zaštite ljudskih prava predstavlja posebno sklisko područje. No, zaključak je autora da je i za Korčulanski statut i za Magnu Cartu nužno istaknuti i to da njihova važnost nije samo u onome što je u njima zapisano i što su predstavljali svojim piscima i njihovim suvremenicima; štoviše, još je važnije njihovo nasljeđe u vidu značenja koje su njihovu sadržaju pripisale kasnije generacije. Mitovi su, naime, ponekad zaista važniji od stvarnosti.

Ključne riječi: Magna Carta, Korčulanski statut, moderne deklaracije o pravima, ljudska prava

\section{UVODNA NAPOMENA}

Statut grada i otoka Korčule, sastavljen davne 1214., a sačuvan u prvoj redakciji iz 1265 . godine, ${ }^{1}$ najstariji je pravni zbornik neke od dalmatinskih srednjovjekovnih

\footnotetext{
1 Napominjemo da glede godine sastavljanja Korčulanskog statuta postoje određeni prijepori. Naime, Korčulanski je statut gotovo sigurno sastavljen 1214. godine, ali taj prvobitni tekst nažalost nije sačuvan. No, na taj tekst izrijekom se poziva kasnija redakcija Statuta: "Ovo su statutarne odredbe i naredbe Komune i ljudi grada i otoka Korčule, učinjene... tisuću dvjesto četrnaeste godine". Nadalje, u prilog toj tvrdnji govore i mišljenja brojnih uglednih povjesničara. Navedeno smatramo sasvim solidnim temeljima za zaključak o postojanju Statuta iz 1214. godine. Pa ipak, neki su autori neskloni takvoj dataciji te, 'igrajući na sigurno', uzimaju 1265. kao godinu nastanka Statuta jer je ta redakcija iz 1265. godine najstariji sačuvani tekst Statuta. No, u svakom slučaju, bez obzira na to kojem se zaključku priklonili, ostaje činjenica da je Korčulanski statut najstariji sačuvani pravni zbornik neke od dalmatinskih srednjovjekovnih komuna. O godini nastanka i nekim argumentima u korist postojanja "prvobitnog" korčulanskog Statuta vidi više u tekstu prof. Zvonimira Šeparovića, Statut grada i otoka Korčule, Grafički zavod Hrvatske, Zagreb, 1987., str. XI.-XII.
} 
komuna, pa je time i najstariji pravni kodeks hrvatskog naroda. ${ }^{2}$ Čitajući odredbe Korčulanskog statuta i zadržavajući se pritom ponajviše na onima ustavnopravnog karaktera koje govore o organizaciji vlasti u komuni te o jamstvima nekih prava njezinim građanima, imajući pritom stalno na umu 1214. kao godinu nastanka Statuta, razmišljali smo o mogućnosti i eventualnoj opravdanosti njegove usporedbe s jednim nadaleko poznatim dokumentom koji izvorno pripada povijesti britanske ustavnosti, a danas se smatra jednim od temelja modernog konstitucionalizma zapadnog svijeta.

Riječ je o dokumentu koji je potpisan 1215. godine pod nazivom Magna Carta ili Magna Carta Libertatum - odnosno Velika povelja (sloboda). ${ }^{3}$ Magna Carta, dakle, godinu je dana mlađa od Korčulanskog statuta, a važna osamstota obljetnica njezina usvajanja bila je obilježena širom svijeta. No, nije u pitanju samo ta vremenska poveznica između ovih dvaju dokumenata. Naime, Magna Carta svakako predstavlja temelj daljnjeg ustavnog razvoja Britanije, ali i rudimentarni izraz vladavine prava u začetku, odnosno historijsku preteču modernog konstitucionalizma. Jer, konstitucionalizam kao ideja, kao koncept utemeljen je na (barem) dva fundamentalna zahtjeva: ograničavanje suverene vlasti te zaštitu prava i sloboda građana. ${ }^{4}$ A oba ta zahtjeva - da se postave neke više ili manje jasne granice obnašanju javne vlasti, te da se istodobno propišu neke garancije prava na koja mogu računati pojedinci, članovi zajednice - koja prema uvriježenom shvaćanju nesumnjivo sadržava britanska Magna Carta, javljaju se i u našem Korčulanskom statutu.

Namjera nam je stoga u radu prvo ukratko ukazati na relevantne odredbe i značaj Magne Carte kao preteče modernih deklaracija o pravima, pa se samo kratko osvrnuti na suvremena shvaćanja i uvriježene klasifikacije ljudskih prava te sustave njihove zaštite, a zatim i prikazati usporedive odredbe Korčulanskog statuta koje, prema našem mišljenju, također predstavljaju nagovještaj modernih garancija prava i sloboda. Pritom u Korčulanskom statutu pronalazimo i neke odredbe, poput, primjerice, ograničavanja trgovanja robljem, koje Magna Carta ne

2 Prof. Antun Cvitanić upozorava da je Korčulanski statut, "poslije Ruske pravde iz XI., odnosno XII. stoljeća, najstariji pravni spomenik svih Slavena uopće", te podsjeća i na činjenicu da je stariji od svih drugih naših kodeksa čiji su tekstovi sačuvani - npr. Dubrovačkog statuta iz 1272., Vinodolskog zakona iz 1288., Bračkog statuta iz 1305., Splitskog statuta iz 1312. etc. Usp. Cvitanić, A., Statut grada i otoka Korčule, Grafički zavod Hrvatske, Zagreb, 1987., str. XV.-XIX. et passim.

3 Glede korištenja različitih naziva treba napomenuti da je izvorni dokument iz 1215. godine nosio naziv Magna Carta, da je zatim više puta izmijenjen i ponovo potvrđen, a da je naziv Magna Carta Libertatum ušao u upotrebu tek kasnije i to nakon što je kralj Edward I. poveljom iz 1297. potvrdio raniju povelju (riječ je konkretno o povelji kojom 1237. kralj Henry III. potvrđuje da će poštovati "Libertates Magnae Cartae") i pritom je nazvao "Magna Carta de Libertatibus Angliae". Opširnije vidi u Avramović, S., "Magna Carta Libertatum", u Temelji moderne demokratije - izbor deklaracija i povelja o ljudskim pravima (1215-1989), IRO Nova knjiga, Beograd, 1989., str. 47-48.

4 Konstitucionalizam se može definirati i kao skupinu načela koja služe upravljanju političkom zajednicom. Ta načela omogućavaju ograničavanje vlasti, zaštitu temeljnih prava, postojanje neovisnog sudstva kao potpore ostvarivanju prava, slobodne izbore s općim pravom glasa, kao i učvršćivanje vladavine prava koja označava odsustvo arbitrarnosti i jednakost svih pred zakonom. Tako o konstitucionalizmu piše prof. Arsen Bačić. Više o evoluciji, definicijama i značenjima konstitucionalizma vidi u Bačić, A., Hrvatska i izazovi konstitucionalizma, Književni krug, Split, 2001., str. 9-23 et passim. 
poznaje. Dakako, svjesni smo samorazumljive činjenice da pri povlačenju paralela između srednjovjekovnih i modernih dokumenata i procjeni značenja pojedinih odredaba i instituta nužno treba biti oprezan, vodeći računa o vremenu iz kojega potječu, ${ }^{5}$ a u tom smislu problematika zaštite ljudskih prava predstavlja posebno sklisko područje. No, i za Korčulanski statut i za Magnu Cartu vrijedi istaknuti i to da njihova važnost nije samo u onome što je u njima zapisano i što su predstavljali svojim piscima i njihovim suvremenicima; štoviše, još je važnije njihovo nasljeđe u vidu značenja koje su njihovu sadržaju pripisale kasnije generacije. Mitovi su, naime, ponekad zaista važniji od svarnosti. ${ }^{6}$

\section{MAGNA CARTA}

Magna Carta ispregovarana je te konačno potpisana na livadi Runnymede $\mathrm{u}$ dramatičnom periodu britanske povijesti, nakon dugotrajne konfrontacije između kralja Johna i njegovih plemića, koja je u konačnici dovela i do izbijanja građanskog rata. Kralj John, koji je prijestolje preuzeo 1199. godine od svojeg brata Richarda I. te je zatim predvodio niz neuspješnih osvajačkih pohoda koji su mu priskrbili omalovažavajuće, pogrdne (ali itekako duhovite) nadimke "Sans Terre" i "Softsword", svoje je plemiće posebno razjario nametanjem visokih poreza i drugih davanja kojima je financirao ratove. Po povratku u Englesku 1214. godine, nakon neuspješnog pokušaja da povrati Normandiju i druge izgubljene posjede u Francuskoj, kralj John se suočio s otvorenom pobunom plemića koji su u svibnju 1215. preuzeli kontrolu nad Londonom. Sukobi i pregovori koji su uslijedili rezultirali su potpisivanjem Velike povelje sloboda 15 . lipnja $2015 .{ }^{7}$

Kakvo je značenje tog dokumenta danas? Magna Carta za neke danas predstavlja, riječima poznatog britanskog suca lorda Irvinea, tek "udaljeni ustavni eho", dokument kojim je uska skupina bogatih plemića nastojala sebi osigurati političku korist, stanovite povlastice i slobode, pa i pravo pobune protiv nepravedne ili arbitrarne kraljevske vlasti. U praktičnom smislu ona je svojevrsni mirovni ugovor između kralja i pobunjenih plemića i predstavlja "kulminaciju dugotrajnih teških pregovora i vještog manevriranja", odnosno pokušaj rješenja političke krize (doduše

5 U tom smislu i N. Lonza u radu o Dubrovačkom statutu: "U pristupu Statutu kao pravnopovijesnom vrelu treba pripaziti da se ne bi prošlim realitetima pridavala suvremena značenja, natezale paralele $\mathrm{i}$ tražile poruke i vrijednosti kojih u nekom srednjovjekovnom tekstu ne može biti". Lonza, N., "Dubrovački statut, dionik europske pravne baštine i knjiga svih zakona", Vijenac, br. 485 od 4. listopada 2012., Matica hrvatska; dostupno na: http://www.matica.hr/vijenac/485/Dubrova\%C4\%8Dki\%20statut,\%20dionik\%20 europske\%20pravne\%20ba\%C5\%A1tine\%20i\%20knjiga\%20svih\%20zakona/.

6 Vidi Lord Bingham, cit. pr. Hill, M., "Magna Carta's Legacy: Common Law and Human Rights", Comparative Law Review, Vol. 5, str. 1, dostupno na: http://www.ecclaw.co.uk/wp-content/ uploads/2014/11/Magna-Cartas-Legacy-Common-Law-and-Human-Rights.pdf.

7 Smatramo interesantnim napomenuti da su do danas sačuvana 4 originalna primjerka Magne Carte iz 1215. godine i svi se nalaze u Engleskoj (dva primjerka se čuvaju u British Library, dok se po jedan nalazi u katedralama u Lincolnu i Salisburyju). U prigodi obilježavanja osamstote godišnjice sva su četiri primjerka bila prvi put u povijesti izložena na jednom mjestu. Usp. internetske stranice British Library, https://www.bl.uk/. 
neuspješan, jer je već u rujnu iste godine buknuo građanski rat). ${ }^{8}$ No, za mnoge druge ona je ipak puno više od toga - Magna Carta ustavni je dokument iznimnog značaja, ali i trajan znamen slobodarskog duha. ${ }^{9} \mathrm{U}$ tom smislu nije joj nimalo naškodila hitra osuda pape Inocenta koji je nedugo nakon njezina potpisivanja, na zahtjev kralja Johna, u svojoj buli od 24. kolovoza 1215. proglasio Magnu Cartu "nezakonitom, nepravednom i sramotnom za engleski narod" te je ukinuo "za sva vremena". ${ }^{10}$

Dakle, s vremenom se njezino značenje mijenja, značaj i domašaj njezinih odredaba šire se prateći društvene i političke promjene. ${ }^{11}$ Premda je Magna Carta nastala prvenstveno kao reakcija na tiransku vladavinu kralja Johna, odnosno kao posljedica pobune plemića i nastojanja kralja da izbjegne građanski rat te sačuva prijestolje, ona se nije ograničila samo na utvrđivanje odnosa između kralja i plemića. Na to nam, naime, ukazuju njezine najvažnije odredbe - a to su, prije svih, čl. 39. i čl. 40. (kasnijom revizijom iz 1225. objedinjeni u čl. 29.) - koje su, da i to napomenemo, na snazi i danas. ${ }^{12}$

Čl. 39. sadržava garanciju da nitko neće biti lišen slobode niti će mu biti oduzeta imovina bez zakonitog postupka: "Nijedan slobodni čovjek neće biti ubijen ili zatvoren, ili lišen svojih prava ili imovine, ili stavljen izvan zakona i prognan, ili na bilo koji način lišen svojeg položaja, niti ćemo protiv njega upotrijebiti silu ili uputiti druge da to učine, osim na temelju zakonite presude njemu jednakih ili/i prava zemlje."13

Čl. 40. Magne Carte pak utvrđuje da će kralj osigurati pravdu za sve: "Pravo $i$ pravdu nećemo nikome prodati, uskratiti ili odgoditi". ${ }^{14}$

Riječ je, dakle, o garancijama koje danas, drugačije formulirane, sadržavaju brojni moderni dokumenti kojima se jamče ljudska prava, kako internacionalni

8 Holt, J. C., Magna Carta (2nd ed.), Cambridge University Press, Cambridge, 1992., str. 6. Vidi i Lord Irvine of Lairg, The Spirit of Magna Carta Continues to Resonate in Modern Law, Parliament of Australia, Papers on Parliament No. 39, December 2002; dostupno na: http://www.aph.gov.au/.

9 Zanimljivo je istaknuti činjenicu podudarnosti trajanja pontifikata pape Inocenta III. (1198. 1216.) i vladavine kralja Johna (1199. - 1216.). O brojnim i različitim interpretacijama Magne Carte vidi u Holt, C. J., op. cit., str. 553.

10 Podatke i sadržaj papinske bule usp. na: http://www.bl.uk/collection-items/the-papal-bullannulling-magna-carta.

11 Nakon smrti kralja Johna u listopadu 1216., prijestolje preuzima njegov devetogodišnji sin Henry, koji kao kralj Henry III. vlada Engleskom sve do 1272. Odmah po Henrijevom preuzimanju prijestolja u njegovo je ime ponovno izdana djelomično izmijenjena Magna Carta s ciljem pomirbe s odmetnutim plemićima. Već sljedeće 1217. godine izdana je još jedna verzija, da bi konačno 1225. godine Magna Carta bila još jednom izdana, ovaj put sa znatnijim izmjenama. Tu treću revidiranu verziju potvrdio je kasnije kralj Edward I. i uvrstio je 1297. u službeni popis zakona (Statute Roll).

12 Osim u tekstu navedenih članaka 39. i 40., danas su od izvornih odredaba, uz određene izmjene, pravno važeće one iz čl. 1. (status engleske Crkve) te čl. 13. (status Londona).

13 Tekst Magne Carte u prijevodu na engleski jezik dostupan je na internetskim stranicama British Library: "Art. (39) No free man shall be seized or imprisoned, or stripped of his rights or possessions, or outlawed or exiled, or deprived of his standing in any other way, nor will we proceed with force against him, or send others to do so, except by the lawful judgement of his equals or by the law of the land"; na: http://www.bl.uk/treasures/magnacarta/translation/mc_trans.htm.

14 Magna Carta: "Art. (40) To no one will we sell, to no one deny or delay right or justice". Tekst dostupan na: http://www.bl.uk/treasures/magnacarta/translation/mc_trans.htm. 
tako i nacionalni, uključujući tu dakako i hrvatski Ustav. Svakako bi bilo prilično teško iz ove srednjovjekovne odredbe iščitati jasno jamstvo suđenja pred neovisnom porotom, no ona ipak predstavlja priznanje jednog važnog načela - nadređenosti prava nad arbitrarnošću. Nadalje, premda se ova garancija na prvi pogled odnosi na 'sve slobodne ljude', dakle isključuje samo robove, potrebno je podsjetiti da njom nisu bili obuhvaćeni kmetovi (na njih se, naime, primjenjivalo lokalno običajno pravo - local custom in his lord's court). Prema tome, 1215. ova je odredba zapravo obuhvaćala veoma mali postotak stanovnika Engleske. No, ona se tumačila široko, pa je već slavni engleski sudac Edward Coke u 17. st. tvrdio da ona uključuje sve građane, a jedan od najuglednijih suvremenih engleskih historičara i proučavatelja Magne Carte J. C. Holt ističe izuzetan stupanj pravne jednakosti koji ona jamči. ${ }^{15}$ Upravo je Cokeova interpretacija Magne Carte, a posebno njezina čl. 39., možda i presudno utjecala na značaj koji joj se nakon 17. stoljeća počinje pridavati, odnosno na njezin globalni utjecaj danas. ${ }^{16}$ Naime, Coke je povezao čl. 39. Magne Carte sa zabranom mučenja, pravima habeas corpusa, pravom na pravični postupak te vladavinom prava.

Osim ove dvije najčešće citirane i analizirane odredbe, Magna Carta sadržava još neka zanimljiva jamstva, poput onoga obuhvaćenog čl. 20. koji utvrđuje da izrečene novčane kazne moraju biti razmjerne težini prekršaja, vodeći pritom računa da to bude isključivo u mjeri koja neće ugroziti materijalnu egzistenciju počinitelja. ${ }^{17}$

\section{MODERNE DEKLARACIJE LJUDSKIH PRAVA I INTERNACIONALIZACIJA NJIHOVE ZAŠTITE}

Magna Carta, dakle, sadržava jamstva nekih osobnih prava, prava koja uz ona politička spadaju u tzv. prvu generaciju prava i sloboda. Ona poslije, krajem 18. stoljeća, redom bivaju uključena u prve cjelovitije deklaracije ljudskih prava Francusku deklaraciju o pravima čovjeka i građanina iz 1789. te američku Povelju o pravima iz 1791. godine. Ti su dokumenti, kojima se prvi put svim građanima jamče neka osobna i politička prava, poslužili kao temelj izgradnje modernih nacionalnih sustava zaštite ljudskih prava.

No, oni su također bili svojevrsni okidač za intenziviranje međunarodnih napora u obrani prava čovjeka, odnosno za internacionalizaciju problematike zaštite ljudskih prava. Tako je razvoj koji je započeo tijekom 19. stoljeća svoju kulminaciju

15 Vidi Lord Irvine of Lairg, op. cit., str. 4.

16 Zbog toga P. Linebaugh doprinos Edwarda Cokea ocjenjuje na sljedeći način: "Edward Coke was the hero of the Magna Carta's chapter 39 and its myth-maker... Coke's 17th-century interpretation shaped the Magna Carta's global reach". Usp. Linebaugh, P., "The Secret History of the Magna Carta", Boston Review, Summer 2003, dostupno na: http://bostonreview.net/archives/BR28.3/linebaugh.html.

17 Magna Carta: "Art. (20) For a trivial offence, a free man shall be fined only in proportion to the degree of his offence, and for a serious offence correspondingly, but not so heavily as to deprive him of his livelihood. In the same way, a merchant shall be spared his merchandise, and a villein the implements of his husbandry, if they fall upon the mercy of a royal court. None of these fines shall be imposed except by the assessment on oath of reputable men of the neighbourhood". Ibid. 
doživio nakon osnivanja Ujedinjenih naroda pod čijim su okriljem usvojeni prvo Opća deklaracija o ljudskim pravima 1948., a zatim i brojni drugi dokumenti poput Međunarodnog pakta o građanskim i političkim pravima, Međunarodnog pakta o ekonomskim, socijalnim i kulturnim pravima etc.

Također treba podsjetiti na činjenicu da je proces internacionalizacije ljudskih prava zatim dobio posebno ubrzanje zahvaljujući pogotovo regionalnim međunarodnim organizacijama, pa tako danas postoje regionalni sustavi zaštite ljudskih prava na europskom, američkom i afričkom kontinentu. ${ }^{18}$ Štoviše, upravo je na tlu Europe, ponajprije zahvaljujući djelovanju Vijeća Europe i usvajanju Europske konvencije o zaštiti ljudskih prava i temeljnih sloboda 1953. godine, stvoren najefikasniji međunarodni sustav zaštite prava čovjeka uopće. U procesu transformacije Europe u prostor realizacije zbiljske međunarodne vladavine prava, kada je o mogućnostima zaštite ljudskih prava riječ, značajan doprinos dala je i druga europska regionalna organizacija - Europska unija, pod čijim je okriljem 2000. godine usvojena Povelja o temeljnim pravima. ${ }^{19}$

Danas se pod ljudskim pravima podrazumijevaju univerzalne pravne garancije koje štite pojedince i grupe od onih aktivnosti kojima se narušavaju njihove temeljne slobode i ljudsko dostojanstvo. Neke od njihovih najvažnijih karakteristika danas su sljedeće - ljudska su prava zajamčena međunarodnim standardima, pravno su zaštićena, fokusiraju se na dostojanstvo pojedinca, obvezuju države i državne aktere; ljudska prava ne mogu biti oduzeta niti ih se pojedinac može odreći, ona su međuovisna, povezana i univerzalna. Ljudska prava, dakle, pripadaju svakom ljudskom biću već samim njegovim rođenjem. Ona se ne moraju zaslužiti niti ovise o posebnom društvenom statusu. Ljudska prava danas uključuju ne samo osobna i politička prava tzv. prve generacije, već i ona ekonomska, socijalna i kulturna prava kao tzv. prava druge generacije. Štoviše, ona danas obuhvaćaju i tzv. moderna i postmoderna prava treće generacije, kao što su pravo na zdravi okoliš ili pravo na održivi razvoj. ${ }^{20}$

No, vratimo se na prve deklaracije prava, odnosno još i ranije u srednjovjekovno doba kada su nastali Magna Carta i Korčulanski statut - samorazumljivom pritom smatramo činjenicu da u srednjem vijeku nije moguće govoriti o ljudskim pravima u modernom smislu. Pa ipak, odredbe koje smo spomenuli svjedoče da postoji nepobitna veza između Magne Carte i modernih dokumenata kojima se jamče ljudska prava i temeljne slobode, premda tu vezu dakako ne treba preuveličavati. Magna Carta produkt je vremena nejednakosti i feudalne hijerarhije, vremena $\mathrm{u}$

18 Premda se u izradu Međunarodnog pakta o građanskim i političkim pravima te Međunarodnog pakta o ekonomskim, socijalnim i kulturnim pravima krenulo gotovo neposredno nakon usvajanja Opće deklaracije o pravima čovjeka, nacrti ovih ugovora prihvaćeni su i otvoreni za potpisivanje tek 1966. godine, a na snagu su stupili 1976. - dakle, više od dvadeset godina nakon stupanja na snagu Europske konvencije o zaštiti ljudskih prava.

19 Povelja Europske unije o temeljnim pravima usvojena je i proglašena na summitu Europskog vijeća u Nici 2000. godine kao politička deklaracija, a pravnoobvezujući status definitivno dobija 2009. godine stupanjem na snagu tzv. Lisabonskog ugovora.

20 Opširnije vidi Bačić, P., Zaštita prava čovjeka u europskim organizacijama, Pravni fakultet, Split, 2007. 
kojem ropstvo na tlu Europe još uvijek postoji i u kojem se sporovi još uvijek rješavaju dvobojima, a do priznanja se često dolazi mučenjem. No, unatoč tome, generalno je stajalište modernih pisaca da bi bilo pogrešno i promašeno negirati važnost i doprinos ovog dokumenta modernoj eri ljudskih prava. ${ }^{21}$ Dijeleći takvo viđenje stvari, pridružujemo se sljedećoj ocjeni suca Lairga: "Magna Carta uistinu predstavlja kamen temeljac moderne vladavine prava, dokument koji predstavlja podlogu ključnih ustavnih doktrina, čiji plamen gori u bakljama modernih dokumenata o ljudskim pravima i čiji je duh u modernom pravu i dalje itekako rezonantan".22

\section{STATUT GRADA I OTOKA KORČULE (1214.)}

Odredbe Korčulanskog statuta koje sadrže garancije nekih prava treba promatrati kroz istu dioptriju, odnosno treba ih analizirati s rezervom. U vrijeme u kojem je Statut nastao još nema ni formalnopravne jednakosti svih pred zakonom; ${ }^{23}$ također, i ropstvo je još itekako prisutno. Međutim, u nekim njegovim odredbama, koje se nalaze u različitim redakcijama, jasno prepoznajemo tragove modernih garancija prava i sloboda.

U Statutu tako, prije svega, nalazimo niz odredaba o sudskom postupku koje nam svjedoče o nastojanjima Korčulana da rješavanje sporova u što većoj mjeri urede te da pritom osiguraju određena prava strankama u postupku. Prva odredba koju želimo istaknuti jest ona koja garantira pravo na žalbu.

Pravo na žalbu danas je zajamčeno kako nacionalnim ustavima, tako i međunarodnim ugovorima kojima se štite ljudska prava, primjerice Međnarodnim paktom o građanskim i političkim pravima ${ }^{24}$ te Europskom konvencijom o zaštiti ljudskih prava i temeljnih sloboda u koju je uključeno dodatnim Protokolom br. 7 iz 1984. godine: "Svatko osuđen od suda za kazneno djelo ima pravo od višeg suda tražiti ponovno razmatranje svoje presude ili kazne. Ostvarenje toga prava, kao i razlozi iz kojih se ono može vršiti, uređuju se zakonom" (čl. 2. st. 1.). Konvencijom zajamčeno pravo na žalbu, dakle, odnosi se isključivo na kaznene predmete (uz napomenu da st. 2. istog članka predviđa i mogućnost iznimki u

21 Vidi Lord Irvine of Lairg, The Spirit of Magna Carta Continues to Resonate in Modern Law, Parliament of Australia, Papers on Parliament no. 39, 2002.

22 Ibid.

23 Tako prof. Cvitanić koji, međutim, na istom mjestu primjećuje i da na Korčuli nije bilo "ni tako izrazite nejednakosti kao u drugim razvijenim sredinama". Statut grada i otoka Korčule, Grafički zavod Hrvatske, Zagreb, 1987., str. XXXV.

24 Međunarodni pakt o građanskim i političkim pravima, prijevod dostupan na: http://www.uljppnm. vlada.hr/. Pravo na žalbu zajamčeno je čl. 2. Pakta. Zanimljivo je, međutim, napomenuti da prof. Alan Uzelac upozorava kako je zapravo riječ o pogrešnom prijevodu jer engleski izraz legal remedy, koji se u Paktu koristi, podrazumijeva: "u najširem smislu sinonim za put pravne zaštite", a ne "pravni lijek" ili "žalbu". Vidi Uzelac, A., "Ustavno pravo na žalbu u građanskim stvarima: jamstvo ispravnog pravosuđenja ili relikt prošlosti?", u: Uzelac, A. et al. (ur.), Djelotvorna pravna zaštita u pravičnom postupku - Liber Amicorum Mihajlo Dika, Pravni fakultet, Zagreb, 2013., str. 235. 
određenim slučajevima), ${ }^{25}$ dok se glede "predmeta u kojima se odlučuje o tzv. pravima i obvezama građanske naravi" u praksi Europskog suda za ljudska prava iskristaliziralo stajalište prema kojem pravo na žalbu u potonjim predmetima nije apsolutno nužno. ${ }^{26} \mathrm{Za}$ razliku od citiranog rješenja, Ustav RH u čl. 18. st. 1. sadrži šire određenje prava na žalbu koje se osim na kaznene odnosi i na građanske te na upravne predmete: "Jamči se pravo na žalbu protiv pojedinačnih pravnih akata donesenih u postupku prvog stupnja pred sudom ili drugim ovlaštenim tijelom". ${ }^{27}$ Korčulanski statut pak sadržava jamstvo prava na žalbu u građanskim i kaznenim predmetima:

"Isto tako određeno je da se (protiv) svake pojedine presude, kako građanske tako $i$ krivične, može uložiti žalba, ako se onaj protiv kojega je presuda donesena smatra oštećenim i hoće da se žali, a to mora učiniti u roku od osam dana nakon donošenja presude. A Kurija mu mora utvrditi rok u kojemu tu žalbu mora proslijediti, jer ako ne uloži žalbu ili (je) ne proslijedi u roku, ne može (se) nipošto poništiti (prvobitna presuda)". ${ }^{28}$

Pravo na žalbu ima danas posebnu važnost u kaznenom, pa i u upravnom postupku. ${ }^{29} \mathrm{U}$ kaznenom postupku žalba predstavlja redovni pravni lijek, ali i nužni uvjet da se priđe preispitivanju donesene odluke, s obzirom na to da se presude preispituju samo na inicijativu stranaka. Kao što možemo vidjeti, i Korčulanski statut utvrđuje isto te strankama određuje rok za ulaganje žalbe i to "... osam dana nakon donošenja presude. A Kurija mu mora utvrditi rok u kojemu tu žalbu mora proslijediti...", a neulaganje žalbe te nepoštovanje odnosno prekoračenje žalbenog roka ima za posljedicu da se "... ne može nipošto poništiti (prvobitna presuda)".

Inače, Statut na mnogim mjestima utvrđuje različite rokove u sudskom prostupku, kao primjerice u odredbi o roku za pristupanje sudskoj raspravi, ${ }^{30}$ zatim za odgovor na tužbu (ovisno o vrijednosti predmeta spora i to po načelu što manja vrijednost to kraći rok, s tim da se udovici daje dvostruko dulji rok negoli odraslom muškarcu) ${ }^{31}$ itd.

Druga skupina odredaba Korčulanskog statuta koje želimo posebno istaknuti jesu jamstva prava na obranu okrivljenika u sudskom postupku. Slična takva jamstva neizostavni su dio modernih povelja o pravima i slobodama u sklopu garancija prava na pravično (pošteno) suđenje. Europska konvencija o zaštiti ljudskih prava,

25 Moguće iznimke od jamstva prava na žalbu u kaznenim predmetima koje predviđa čl. 1. st. 2. Protokola br. 7 odnose se na sljedeće slučajeve: 1) lakša kaznena djela; 2) slučajevi u kojima je nekoj osobi u prvom stupnju suđeno pred najvišim sudom; 3) ako je osoba osuđena povodom žalbe protiv oslobađajuće presude. Europska konvencija o zaštiti ljudskih prava i temeljnih sloboda, NN-MU br. 6/99.

26 Tako Uzelac, A., "Ustavno pravo na žalbu u građanskim stvarima: jamstvo ispravnog pravosuđenja ili relikt prošlosti?", u: Uzelac, A. et al. (ur.), Djelotvorna pravna zaštita u pravičnom postupku - Liber Amicorum Mihajlo Dika, Pravni fakultet, Zagreb, 2013., str. 223. et passim.

27 Ustav RH, NN br. 85/2010 (pročišćeni tekst).

28 Statut grada i otoka Korčule, Grafički zavod Hrvatske, Zagreb, 1987., Gl. XXV, str. 41.

29 O pravu na žalbu u upravnom postupku vidi npr. Đerđa, D. i Galić, A., "Žalba u upravnom sporu", Zbornik radova Pravnog fakulteta u Splitu, sv. 51, br. 2, 2014., str. 339-362.

30 Statut grada i otoka Korčule, Grafički zavod Hrvatske, Zagreb, 1987., Gl. III, str. 26.

31 Statut grada i otoka Korčule, Grafički zavod Hrvatske, Zagreb, 1987., Gl. XXX, str. 17. 
primjerice, u čl. 6. "Pravo na pošteno suđenje" jamči svakoj optuženoj osobi pravo na obranu u postupku te navodi niz garancija koje se moraju osigurati optuženiku u kontekstu pravednog suđenja. ${ }^{32}$ Sukladno praksi Europskog suda za ljudska prava u Strasbourgu te sistematizaciji suvremenih autora, A. Uzelac izdvaja sljedeće elemente prava na pošteno suđenje: pravo na pristup sudu; pravo na pravnu pomoć; pravo na procesnu ravnopravnost; pravo na javno i kontradiktorno suđenje; pravo na saslušanje; pravo na dokaz; pravo na javnu objavu presuda; pravo na sud ustanovljen zakonom; pravo na nezavisnost i nepristranost u suđenju; pravo na suđenje u razumnom roku; pravo na učinkovitu ovrhu presuda; zabranu arbitrarnog postupanja. ${ }^{33}$ Ustav RH također jamči okrivljenim osobama cijeli niz prava, između ostalog i pravo na branitelja po vlastitom izboru, odnosno na besplatnog branitelja ukoliko nemaju dovoljno sredstava (čl. 29). ${ }^{34}$

Neke elemente prava na pošteno suđenje predviđa i Korčulanski statut. Statutom je naime prije svega utvrđeno da nitko ne može biti osuđen ako prethodno nije pozvan da se brani:

"Isto tako određujemo da se nijedan muškarac ni žena ne mogu krivično osuditi ako ih prije (komunalna) uprava nije pozvala da se brane, a ako ne bi htjeli pristupiti (sudu) ili odgovarati, neka se kao krivci presudom osude (za ono) za što su optuženi". ${ }^{35}$

Nadalje, Korčulanski statut osigurava otočanima, ali i strancima, pravo na pravnu pomoć u sudskim postupcima. Tako su svakih šest mjeseci knez i Malo vijeće birali dva (prema kasnijim odredbama četiri) odvjetnika, koji su pod zakletvom i s pravom na nagradu u iznosu od "jednog velikog denara" za svaki spor morali "štititi prava, kako otočana tako i stranaca, i braniti pred gospodinom (knezom) i njegovim sucima ili izbranim sucima prava $i$ interese svojih stranaka". ${ }^{36}$

Statut dakle jamči strankama pravo na branitelja tj. odvjetnika u sudskom postupku te tako potvrđuje i ovaj važni aspekt moderne garancije prava na pošteno suđenje. Iz nekih drugih odredaba doznajemo, međutim, i da to pravo nije univerzalno, odnosno da protjerani građani te neke druge kategorije građana nemaju pravo na branitelja, kao i da za pojedince "iz boljeg roda" to ograničenje ne vrijedi. ${ }^{37}$ Tekst Statuta pruža nam dokaz i o tome da se korčulanski komunalni odvjetnici nisu uvijek spremno odazivali na poziv da strankama u postupku pruže svoje usluge; no, korčulanske su gradske vlasti takvo izbjegavanje odvjetničkih dužnosti, iz razloga

32 O aspektima prava na pošteno suđenje koji su izrijekom sadržani ili su izvedeni iz čl. 6. Konvencije vidi u Omejec, J., Konvencija za zaštitu ljudskih prava i temeljnih sloboda u praksi Europskog suda za ljudska prava, Novi informator, Zagreb, 2013., str. 1124 et passim.

33 Uzelac, A., "Pravo na pravično suđenje u građanskim predmetima: Nova praksa Europskog suda za ljudska prava i njen utjecaj na hrvatsko pravo i praksu", Zbornik Pravnog fakulteta u Zagrebu, sv. 60, br. 1, 2010., str. 104.

34 Ustav RH, NN 85/2010 (pročišćeni tekst).

35 Statut grada i otoka Korčule, Grafički zavod Hrvatske, Zagreb, 1987., Gl. CXXVIII., str. 72.

36 Statut grada i otoka Korčule, Grafički zavod Hrvatske, Zagreb, 1987., Gl. XXVI, str. 16.

37 Statut grada i otoka Korčule, Grafički zavod Hrvatske, Zagreb, 1987., G1. III, str. 26 i Gl. CXCVII str. 159. 
što takvo ponašanje ide "na štetu prava i pravice i propast siromašnih osoba", odlučile sankcionirati na način da odvjetnici moraju platiti kaznu ako uskrate pravo na obranu onima koji na to imaju pravo:

"Budući da korčulanski komunalni odvjetnici katkada odbijaju odvjetnikovati za one koji ih (za to) zamole, na štetu prava i pravice $i$ na propast siromašnih osoba... odlučujemo i odlučujući naređujemo (sljedeće): kada god te odvjetnike ili nekoga od njih netko zamoli (da ga zastupaju) a oni uskrate zastupanje i ne budu htjeli braniti prava osoba koje ih (za to) mole, kao što su dužni i što moraju, neka svaki od njih $i$ svaki put odmah upadne u kaznu od pet perpera koji moraju pripasti korčulanskoj komuni...". ${ }^{38}$

U ovom kontekstu zanimljive su i odredbe koje iz razloga krvnog ili tazbinskog srodstva sa strankom u postupku dopuštaju izuzeće odvjetnicima ("... ako je zakleti odvjetnik s nekim (od stranaka) u sporu u drugom i bližem stupnju krvnog srodstva... nije dužan odvjetnikovati protiv njega ako neće"), ${ }^{39}$ ali i svjedocima ("... nitko tko je s nekim u trećem i bližem stupnju (srodstva), ili (mu) je pašanac po majci ne može za njega svjedočiti, ali protiv njega može"). ${ }^{40}$ Iz istih razloga Statut predviđa i isključenje sudaca iz sudskog postupka (... ako koji sudac ili vijećnik bude u trećem stupnju krvnog srodstva i bližem s nekim tko ima spor pred sudom, odnosno kome bude trebalo Vijeće, ili (mu) je pašanac, u tom slučaju na sudu ili u Vijeću, neka ga knez isključi, a protivna strana može (o tome) izvijestiti kneza, ako (on) to ne bude znao"). ${ }^{41}$

Kad je o sucima riječ, zanimljivo je istaknuti da Statut štiti i fizički integritet i čast sudaca - za one koji sucu "upute uvredljive riječi" propisuje se plaćanje novčane kazne, ${ }^{42}$ dok je za udaranje suca ("silovito nasrtanje rukama") zapriječena kazna iznosila mjesec dana zatvora, a za teže fizičke nasrtaje bile su predviđene i novčana i zatvorska kazna. ${ }^{43} \mathrm{~S}$ druge strane, "suci batinaši" koji bi fizički nasrnuli na neku osobu i nanijeli joj povredu kažnjavali su se "dvostrukom kaznom od one kojom bi se kaznio svako drugi". ${ }^{4}$

Statutom se jamči i zaštita časti, dostojanstva i ugleda osobe, na način da "tko god nekome uputi uvredljive riječi" mora platiti novčanu kaznu. Novčana je kazna predviđena čak i u slučajevima u kojima osoba kojoj je uvreda bila upućena ne pokrene sudski postupak, ali je uvreda izrečena "u prisustvu (komunalne) uprave koja sjedi za sudačkim stolom": "Ako onaj koji je pretrpio uvredu neće da (ga) tuži, uprava je uza sve to, vezana (vlastitom) zakletvom, dužna kazniti uvreditelja na dva perpera što ih treba zaplijeniti na račun Komune". ${ }^{45}$ Međutim, ako je takvo djelo

\footnotetext{
38 Statut grada i otoka Korčule, Grafički zavod Hrvatske, Zagreb, 1987., Gl. CXCVII, str. 159.

39 Statut grada i otoka Korčule, Grafički zavod Hrvatske, Zagreb, 1987., Gl. XXVII, str. 16.

40 Statut grada i otoka Korčule, Grafički zavod Hrvatske, Zagreb, 1987., Gl. XXXIII, str. 18.

${ }^{41}$ Statut grada i otoka Korčule, Grafički zavod Hrvatske, Zagreb, 1987., Gl. XXVII, str. 26.

2 Statut grada i otoka Korčule, Grafički zavod Hrvatske, Zagreb, 1987., Gl. X, str. 36.

43 Statut grada i otoka Korčule, Grafički zavod Hrvatske, Zagreb, 1987., Gl. VI, str. 35.

Statut grada i otoka Korčule, Grafički zavod Hrvatske, Zagreb, 1987., Gl. XI, str. 35.

45 Statut grada i otoka Korčule, Grafički zavod Hrvatske, Zagreb, 1987., Gl. IX, str. 35-36.
} 
bilo počinjeno na štetu "poštene žene", a od strane kakve "svećeničke priležnice ili priležnice druge osobe", javne bludnice ili možda "žene na zlu glasu i loša života", kazne su bile oštrije - od jednodnevnog vezivanja za stup srama, do šibanja žene na zlu glasu koja pritom, reklo bi se, biva prisiljena trčati oko grada. ${ }^{46}$

Još jedna izuzetno važna odredba koja predstavlja poseban element prava na pravično suđenje jest ona kojom se utvrđuje načelo nadređenosti prava nad arbitrarnošću, odnosno da svaka presuda mora biti zasnovana na statutarnim odredbama ili ustaljenim pravnim običajima:

"...U punom i Velikom vijeću grada i otoka Korčule okupljenom u crkvi Svetoga Marka u kojem su bila 53 vijećnika, zaključeno je s 52 (glasačke) kuglice, bez obzira (na to što) je pronađena jedna protiv: Ako koja (komunalna) uprava ubuduće, to jest knez, njegov zamjenik, suci i, ako budu s njima, suci Male kurije, donesu neku presudu, građanskopravnu ili krivičnopravnu, protivnu statutarnim odredbama, statutarnim izmjenama i odobrenim i ustaljenim pravnim običajima što su ih priložile ili predočile ili dokazale stranka ili stranke koje se pred sudom spore o (vrijednosti) preko 10 perpera, a onaj tko se osjeća oštećenim hoće da se žali, može to uraditi prema statutarnim odredbama o žalbama glave XXV Staroga statuta.

Ako viši organi nađu da je ta presuda slabo presuđena, a žalba protiv nje pravno zasnovana neka (komunalna) uprava ili dio uprave, ako je (presuda) donesena većinom (njenih) članova (a ne jednoglasno), podlegne i neka plati svu štetu $i$ troškove i gubitke koje je (pretrpjela) i u koje je upala ona osoba protiv koje je ta nepravedna presuda donesena, ( $i$ to) odmah i bez odlaganja, bez obzira na ikoju statutarnu odredbu koja bi propisivala suprotno. Izuzetak je ipak statutarna glava o pastirima koja ostaje na snazi. Ako pak onaj koji se žali izgubi svoje pravo, neka plati Komuni 2 solida po svakom perperu (vrijednosti spora) i neka plati stranci protiv koje je uložio žalbu sve troškove. (Pri tome) je svagda žalitelj dužan dati zalog komunalnom blagajniku, kako za (sudske) troškove tako (i) za plaćanje po procjeni vrijednosti spora i to prije negoli primi spise iz kancelarije". ${ }^{47}$

Ovu odredbu dakle možemo shvatiti kao onodobni izraz jamstva prava na pravično suđenje u smislu nastojanja zabrane arbitrarnog postupanja odnosno jačanja pravne sigurnosti.

Konačno, Korčulanski statut sadržava i dvije odredbe koje se odnose na suzbijanje trgovine robljem. Prva odredba ("Zabrana kupovanja robova") govori zapravo o restrikcijama trgovine robljem u smislu da se svakom Korčulaninu brani kupovanje robova "osim za vlastitu potrebu" kao i sudjelovanje u trgovini robljem na način da bude "... posrednik (u toj trgovini), niti smije neku (ropkinju) dovesti u grad preko onih iz Drijeva (u svrhu trgovine)...", te se istodobno u grad dovedenim ropkinjama kršćanske vjere garantira prestanak ropskog statusa i stjecanje slobode:

46 Statut grada i otoka Korčule, Grafički zavod Hrvatske, Zagreb, 1987., Gl. XII, str. 93. i Gl. XXIX, str. 97.

47 Statut grada i otoka Korčule, Grafički zavod Hrvatske, Zagreb, 1987., Gl. CXVII, str. 120-121. 
"Također iste godine, indikcije i dana 11. studenog, u Velikom vijeću grada i otoka Korčule u punom sastavu, u kojem je bilo 48 vijećnika, (a) nitko od njih nije bio protivan, zaključeno je da nijedan Korčulanin nikako ne može kupiti koju ropkinju ili roba (pod prijetnjom) kazne od pedeset dukata, osim za vlastitu potrebu, niti može biti posrednik ( $u$ toj trgovini), niti smije neku (ropkinju) dovesti u grad preko onih iz Drijeva (u svrhu trgovine). A ako tko dovede neku kršćanku (kao ropkinju, pa) se dokaže da je ona kršćanske vjere, neka je korčulanska komuna oslobodi, a onaj koji ju je doveo, neka (je) izgubi". ${ }^{48}$

U drugoj pak statutarnoj odredbi ("Zabrana trgovanja robovima") nalazimo apsolutnu zabranu trgovine robljem i uopće bilo kakvog učešća u takvoj raboti za stanovnike Korčule, kako domaće tako i strance, uključujući posebno fingiranje patronata korčulanske komune:

"Također iste godine i indikcije, dana pak 9. mjeseca svibnja, zaključeno je, prihvaćeno i potvrđeno da od sada unaprijed, ako bi koji čovjek bilo koje vrsti, stupnja, spola i društvenog položaja, kako Korčulanin tako i stranac stanovnik Korčule, trgovao robljem ili na bilo koji način ili (bilo kakvom) prevarom ili ako bi bio mešetar ili posrednik (u tom poslu) ili pisao isprave (o kupoprodaji) tih robova ili ropkinja ili za to pribavio pečat korčulanske komune, (čini zabranjeno djelo). I ako bi se otkrilo da netko krši tu zabranu i (prekršitelj) bio pronađen i optužen $i$ (to mu) bilo dokazano bar dvojicom vjerodostojnih svjedoka, ili bi bilo očito iz javnog pričanja, svatko (od tih) neka bude dužan neoprostivo platiti sto zlatnih dukata, od kojih dva dijela neka pripadnu i moraju pripasti korčulanskoj komuni, a preostali, to jest treći dio neka pripadne i mora pripasti onome koji prijavi taj zločin. I hoćemo da se ova odluka odnosno statutarna izmjena od sada unaprijed uvijek smatra pravom statutarnom odredbom. A ako koji (prekršitelj) ne bi imao odakle platiti, neka mu se odreže ruka...".49

Ove odredbe svakako ne znače apsolutno ukidanje ropstva (osim za ropkinju za koju se naknadno dokaže da je kršćanske vjere), niti nam bilo što govore o sudbini osoba koje nisu kršćanske vjere i/ili se već nalaze u ropskom statusu, ali jasno ograničavaju odnosno zabranjuju trgovinu robljem i svjedoče o postojanju svijesti o neodrživosti prakse trgovanja ljudima kao robom te nagovještavaju namjeru da se u perspektivi ropstvo dokine. Imajući potonje u vidu, držimo da je značaj ovih statutarnih odredaba izuzetan. Zašto? Kako bismo dobili odgovor, opet ćemo se prebaciti na početak 19. stoljeća i začetke međunarodne zaštite ljudskih prava.

Naime, međunarodni napori u zaštiti prava čovjeka svoje prve konkretne rezultate ostvaruju upravo u borbi protiv ropstva i trgovine robljem. Prvi međunarodni ugovori o suzbijanju trgovine robljem koja se odvijala na Atlantiku potpisani su, međutim, tek tijekom 19. stoljeća. Trgovina robljem odvijala se nesmetano pod državnim patronatom sve do 18. stoljeća; u Engleskoj je humanitarni pokret protiv trgovine robljem vodio William Wilberforce koji je, uz pomoć svojih pristaša, uspio postići da parlament 1807. godine usvoji zakonski akt kojim se formalno zabranjuje

48 Statut grada i otoka Korčule, Grafički zavod Hrvatske, Zagreb, 1987., Gl. XXXVI, str. 99.

49 Statut grada i otoka Korčule, Grafički zavod Hrvatske, Zagreb, 1987., Gl. CXLI, str. 130-131. 
trgovina robljem u Engleskoj, a od 1833. i trgovina robljem na području cijelog Britanskog Imperija. Prvi međunarodni ugovor, deklaracija kojom se trgovina robljem ukida, potpisalo je osam tadašnjih velesila na Bečkom kongresu 1815. godine, a procjenjuje se da je samo u prvom desetljeću 19. stoljeća preko Atlantika prevezeno 600 tisuća robova. ${ }^{50}$

Konačno, o tome koliki je bio raskorak između slova Statuta i njegove primjene u svakodnevnom životu ne možemo suditi, no i kratka usporedba sa slavnom engleskom poveljom navodi na zaključak da bi na reglementacijskoj razini izdržao kušnju komparacije sa svakim sličnim onodobnim dokumentom. Ostajemo pritom uvjereni i da značaj Korčulanskog statuta, bez obzira na znatan interes koji je izazivao te ga i danas pobuđuje u stručnoj javnosti, ipak nije dovoljno valoriziran i to prvenstveno u nacionalnim okvirima. Možda je presmjela tvrdnja da je Statut grada i otoka Korčule u mnogo čemu bio ispred svoga vremena, no snatramo da i za takav zaključak ima čvrstih argumenata.

\section{ZAKLJUČAK}

Za kraj podsjetimo na činjenicu da su klasične deklaracije kojima se jamče prava čovjeka nastale kao reakcija na tiraniju i tiransku vladavinu. Njihovi autori vidjeli su u javnoj vlasti instrument ugroze njihove slobode, prije nego sredstvo za obranu slabijih i njihovih interesa. Postoji li i ovdje paralela s nastankom Korčulanskog statuta? Čini se da postoji - podsjećamo na ono što je zapisao prof. Cvitanić u uvodnoj studiji: "... stanovništvo otoka Korčule, kao i ostale Dalmacije, vrlo rano je osjetilo pretenzije mlade Mletačke Republike i, da bi osujetilo njezine namjere i zaštitilo svoju otočku zajednicu, možda već 1214. godine donijelo svoje prve organizacijsko-pravne norme sabrane u komunalni Statut". ${ }^{51}$

Uvjerenja smo da je već i površnijim čitanjem izabranih odredaba Korčulanskog statuta moguće pronaći poveznicu s modernim garancijama ljudskih prava. Ti tragovi nisu uvijek posve jasni, ponekad i zbunjuju svojom ambivalentnošću, svakako im nedostaju neke karakteristike koje bismo danas uz njih očekivali u kontekstu zaštite ljudskih prava, no ne smijemo zaboraviti da su oni utisnuti u vremenu bitno drugačijem od današnjeg. Čitatelja koji potonje ima stalno na umu ti će tragovi zasigurno odvesti do modernih povelja o pravima i slobodama.

Statut Grada i otoka Korčule predstavlja stoga čvrsti dokaz da je ta mala dalmatinska srednjovjekovna komuna bila čvrsto usidrena u europskoj humanističkoj tradiciji te nam ostaje kao trajni znamen njezina slobodarskog duha.

50 Usp. npr. Martinez, J. S., The Slave Trade and the Origins of International Human Rights Law, Oxford University Press, Oxford - New York, 2012.

51 Cvitanić, A., "Uvod", u: Statut grada i otoka Korčule, Grafički zavod Hrvatske, Zagreb, 1987. str. XVIII. 


\section{ANNOUNCEMENT OF MODERN GUARANTEES OF RIGHTS IN THE KORCULA STATUTE}

The paper points out the relevant provisions and the importance of the Magna Carta as a forerunner of modern declarations of rights, and briefly looks at modern understandings and established classifications of human rights, their protection systems, and looks in more details at comparable provisions of the Statute of the Town and Island of Korčula as undoubtedly representative examples of modern guarantees of rights and freedoms. At the same time, author find some provisions in the Korčula Statute, such as, for example, the restriction of the slave trade, which Magna Carta does not know. The author starts from the fact that, when drawing parallels between medieval and modern documents and assessing the meaning of certain provisions and institutes, one should necessarily be careful, because the issue of human rights protection is a particularly slippery area. However, the author's conclusion is that for both the Korčula Statute and the Magna Carta it is worth pointing out that their importance is not only in what is written in them and what they presented to their writers and their contemporaries; moreover, even more important is their heritage in terms of the meanings ascribed to their content by later generations. Namely, myths are sometimes indeed more important than reality

Key words: Magna Carta, Korčula Statute, modern declarations of rights, human rights 